УДК 661.728.7:577.152.3

\title{
ФЕРМЕНТАТИВНЫЙ ГИДРОЛИЗ ЦЕЛЛЮЛОЗ ИЗ ПЛОДОВЫХ ОБОЛОЧЕК ОВСА ПРИ РАЗЛИЧНЫХ КОНЦЕНТРАЦИЯХ СУБСТРАТА
}

\author{
(ㄱ) Е.И. Макарова", В.В. Будаева, Е.А. Скиба \\ Институт проблем химико-энергетических технологий Сибирского \\ отделения Российской академии наук, ул. Социалистическая, 1, Бийск, \\ 659322 (Россия,) e-mail: ipcet@mail.ru
}

Установлено, что технические целлюлозы, полученные из плодовых оболочек овса комбинированным способом (предгидролиз, щелочная делигнификация, обработка раствором азотной кислоты), обладают высокой реакционной способностью к ферментации при гидролизе смесью ферментных препаратов «Брюзайм ВGX» и «еллолюкс-А». Исследована зависимость прироста редуцирующих веществ от исходной концентрации субстрата в пределах от 15 до 120 г/дм ${ }^{3}$ и выявлено линейное уменьшение конечного выхода редуцирующих веществ (через 72 ч) от 88 до $65 \%$ с ростом начальной концентрации субстрата.

Ключевые слова: техническая целлюлоза; плодовые оболочки овса, щелочная делигнификация с последующей обработкой азотной кислотой, ферментативный гидролиз, редуцирующие вещества, «Брюзайм ВGX», «Целлолюкс-А», концентрация субстрата.

\section{Введение}

Ферментативный гидролиз нередко рассматривается в качестве самостоятельного способа получения новых фундаментальных знаний о поведении субстратов - целлюлозосодержащего сырья или его продуктов переработки - в «мягких» условиях проведения реакции (рН среды в диапазоне 4-5, температура от 40 до $50{ }^{\circ} \mathrm{C}$, продолжительность от 48 до 144 ч, биокатализ индивидуальными ферментами, ферментными препаратами и(или) мультиэнзимными композициями) [1-3]. С точки зрения прикладных наук, прочность лигноцеллюлозной матрицы биомассы в условиях ферментации является главным барьером для экономической реализации производства глюкозо-пентозных гидролизатов в промышленном масштабе. Поэтому необходимость изучения отдельных факторов, влияющих на ферментативный гидролиз чистых целлюлоз, обусловлена стремлением совершенствования процесса ферментативного гидролиза различных видов нативного сырья в целом [4-7].

Как правило, кинетика ферментативного гидролиза целлюлозы характеризуется высокой начальной скоростью накопления глюкозы, которая существенно снижается со временем, в результате чего зачастую наблюдается неполное преобразование биополимера в редуцирующие вещества $[2,4,5]$. Гипотезами для объяснения явления снижения скорости гидролиза являются дезактивация фермента, снижение синергетического эффекта, изменение реакционной способности субстрата и ингибирование фермента продуктами реакции.

Одним из важнейших факторов, определяющих как выход, так и начальную скорость гидролиза, является исходная концентрация субстрата в растворе реакционной массы [8]. Высокая концентрация суб-

Макарова Екатерина Ивановна - аспирант, младший научный сотрудник лаборатории биоконверсии, тел.: (3854) 30-59-85, e-mail: massl@ mail.ru Будаева Вера Владимировна - заведующая лабораторией биоконверсии, кандидат химических наук, тел. (3854) 30-59-85, e-mail: budaeva@ipcet.ru Скиба Екатерина Анатольевна - научный сотрудник лаборатории биоконверсии, кандидат технических наук, тел. (3854) 30-59-85, e-mail: eas08988@ mail.ru страта может стать причиной субстратного ингибирования с соответствующим снижением скорости гидролиза. Степень ингибирования определяется, в первую очередь, концентрацией субстрата, во вторую - соотношением массы фермента к массе субстрата. Кроме того, при проведении ферментации с высокими концентрациями субстрата возникают проблемы

\footnotetext{
* Автор, с которым следует вести переписку.
} 
перемешивания и массопередачи. Анализ литературных источников с описанием одностадийного ферментативного гидролиза целлюлоз с выходами, близкими к 100\%, показал наличие ограниченного количества такого рода примеров [7, 8].

Цель данной работы - исследование ферментативного гидролиза технических целлюлоз, полученных щелочной делигнификацией плодовых оболочек овса с последующей обработкой азотной кислотой, при различных исходных концентрациях субстрата.

\section{Экспериментальная часть}

Аналитические методы. Определение основных характеристик субстратов (массовой доли (м.д.) $\alpha$-целлюлозы, м.д. остаточного (кислотонерастворимого) лигнина, м.д. золы, м.д. пентозанов) проводили по стандартным методикам [9]. Определение влажности осуществляли на анализаторе влагосодержания Ohaus MB 23/MB 25 (США). Степень полимеризации целлюлоз определяли по вязкости растворов в кадоксене на вискозиметре ВПЖ-3 с диаметром капилляра 0,92 мм по методике [10].

Степень кристалличности образцов целлюлозы определена И.В. Люхановой и Л.А. Алешиной (Петрозаводский государственный университет) рентгенографическим методом на дифрактометре ДРОН-3М, погрешность определения составила $\pm 5 \%$ [11].

Исследование субстратов проводили методом растровой электронной микроскопии (РЭМ) на приборе «JSM-840» фирмы «Jeol» с рентгеновским микроанализатором «Link-860» серии II.

Концентрацию редуцирующих веществ (РВ) в пересчете на глюкозу определяли спектрофотометрически на «UNICO UV-2804» (США) с использованием реактива на основе 3,5-динитросалициловой кислоты. Преимуществами данного метода является простота выполнения анализа и малый расход реагентов [12, 13]. Относительная погрешность данного метода составила 3,5\% [14]. Выход РВ (отношение массы РВ к массе субстрата) рассчитан с учетом коэффициента, связанного с присоединением молекулы воды к ангидроглюкозным остаткам соответствующих мономерных звеньев в результате ферментативного гидролиза.

По окончании процесса гидролизаты отфильтровывали от непрореагировавшего субстрата и в гидролизате проводили определение концентрации пентоз в пересчете на ксилозу спектрофотометрически $\mathrm{Fe}^{3+}$-орсиновым способом.

Реактивы и материаль. В качестве субстратов в работе использовали технические целлюлозы из плодовых оболочек овса. Укрупненный образец целлюлозы-сырца был получен в 2011 г. на опытном производстве ИПХЭТ СО РАН трехстадийным способом, заключающимся в предварительной обработке сырья 0,1\%-ным раствором азотной кислоты при температуре $91-93{ }^{\circ} \mathrm{C}$, затем щелочной делигнификацией 4\%-ным раствором гидроксида натрия при той же температуре, после чего воздействием 4\%-ным раствором азотной кислоты при температуре $92{ }^{\circ} \mathrm{C}$ [15]. Данный способ получил название комбинированного, поскольку представляет собой двухступенчатый процесс с применением разнохарактерных реагентов на различных ступенях обработки [16]: щелочной гидроксид натрия и кислый реагент - азотная кислота.

Для более полного гидролиза целлюлоз использовали смесь ферментных препаратов (ФП) «Брюзайм BGX» (поставщик компания «Русфермент», г. Москва) и «Целлолюкс-А» (производитель ПО «Сиббиофарм», г. Бердск). В соответствии с паспортами ФП обладали разными активностями: «Брюзайм ВGX» - целлюлаз-

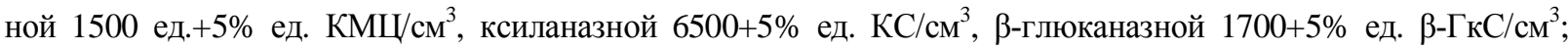
«Целлолюкс-А»- целлюлазной 2000 200 ед./г, ксиланазной 8000 КС и $\beta$-глюканазной $1500 \beta$-ГлС. В соответствии с рекомендациями поставщиков ферментов расходы ФП на 1 г субстрата составили: «Брюзайм

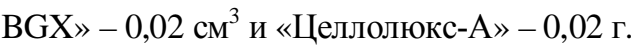

Методы проведения экспериментов. На первом этапе исследования для ферментативного гидролиза целлюлозы в колбу Эрленмейера емкостью 500 мл помещали 5 г субстрата в пересчете на абсолютно сухое

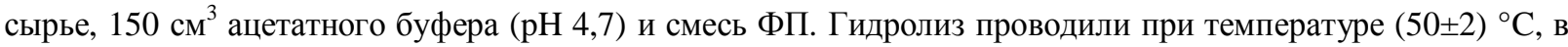
течение 72 ч при постоянном перемешивании. Перемешивание реакционной массы осуществлли на горизонтальной платформе ПЭ-6410М (Россия) с частотой колебания 150 мин $^{-1}$ [17]. Отбор проб объемом 2 см $^{3}$ для определения концентрации РВ осуществляли через каждые 8 ч. По окончании ферментации реакционную массу фильтровали с получением готового гидролизата и твердого осадка остатков субстрата.

На втором этапе исследования ферментацию проводили по описанной выше методике, но с различными исходными концентрациями влажного субстрата в пересчете на абсолютно сухое сырье: 15; 30; 60; $90 ; 120$ г/дм ${ }^{3}$. 


\section{Обсуждение результатов}

Получение и физико-химические свойства субстратов Ц1 и Ц2. Целлюлоза-сырец, полученная на опытном производстве, характеризовалась низкой зольностью 0,28\% и удовлетворительным значением массовой доли кислотонерастворимого лигнина 1,70\%. Тем не менее с влажной технической целлюлозой был проделан ряд процедур для удаления примесей, в результате которых были определены условия получения целлюлозы с содержаниями лигнина и золы менее $0,5 \%$. Влажную целлюлозу-сырец обработали 2,0\%-ным раствором $\mathrm{NaOH}$ при $60{ }^{\circ} \mathrm{C}$, промыли 0,2\%-ным раствором $\mathrm{NaOH}$, затем водой, после чего обработали $1 \%$-ным раствором $\mathrm{HNO}_{3}$, промыли водой, обработали водным этиловым спиртом, затем спиртом, отжали и высушили, не допуская образования комков в процессе сушки. Полученная таким образом целлюлоза в количестве 2 кг, обозначенная образец Ц1, представляла собой сыпучий волокнистый порошок, в котором под микроскопом видны отдельные плоские прозрачные волокна целлюлозы.

Аналогичным образом, но с исключением стадий обработки водным спиртом и сушки, был наработан образец влажной целлюлозы массой 10 кг, который был обозначен как образец Ц2. Влажность и массовые доли основных компонентов субстратов Ц1 и Ц2 в пересчете на абсолютно сухое вещество представлены в таблице 1 .

Химический состав субстратов большей частью представлен гидролизуемыми компонентами - целлюлозой и пентозанами. Очень малая доля относится

Таблица 1. Характеристики субстратов

\begin{tabular}{l|c|c}
\hline \multicolumn{1}{c|}{ Показатель } & Ц1 & Ц2 \\
\hline Влажность, \% & 3,3 & 73,3 \\
$\alpha$-целлюлоза, \% & 88,4 & 90,0 \\
Остаточный лигнин, \% & 0,4 & 0,5 \\
Золы, \% & 0,16 & 0,12 \\
Пентозаны, \% & 11,0 & 11,3 \\
Степень полимеризации, ед. & 1350 & 1140 \\
Степень кристалличности, \% & 67 & 68 \\
\hline
\end{tabular}
к негидролизуемым примесям - остаточному лигнину и золе. Степени полимеризации и степени кристалличности обеих целлюлоз с учетом определения погрешности очень близки. Все это позволяет предположить одинаковую реакционную способность обоих субстратов, в то же время следует подчеркнуть, что они характеризуются высокими значениями как степени полимеризации, так и степени кристалличности.

Результаты РЭМ (рис. 1) показали, что частицы субстрата представляют собой изогнутые плоские волокна с гипертрофированной поверхностью толщиной 2-5 мкм, шириной 20-30 мкм и длиной 300-800 мкм. Пластинчатая форма данных целлюлоз обусловлена их морфологическим происхождением. Они получены из плодовых оболочек злака - чешуек целлюлозной ткани, многослойно покрывающих зерно и выполняющих защитную функцию. Представленные результаты РЭМ демонстрируют отсутствие скрученных клубков волокон, а следовательно, доступность всех элементов поверхности единичных волокон. Увеличение в 3000 раз единичного волокна позволяет рассмотреть сложную организацию плоской поверхности целлюлозы с многочисленными углублениями ячеистого характера, располагающего к адсорбции ФП на субстрате.

Ферментативный гидролиз субстратов Ц1 и Ц2. На первом этапе работы исследовалась реакционная способность к ферментации Ц1 и Ц2, причем субстрат Ц1 был взят для ферментации в сухом состоянии, а Ц2 - во влажном с учетом массовой доли воды в навеске субстрата. Реакционная способность целлюлоз при ферментативном гидролизе была оценена по накоплению продуктов реакции - РВ в реакционной смеси. Зависимость концентрации РВ в гидролизате от продолжительности ферментации образцов Ц1 и Ц2 представлена на рисунке 2.

Как следует из представленных на рисунке 2 результатов, образцы Ц1 и Ц2 обладают высокой реакционной способностью. Для них характерна значительная скорость накопления РВ в начальный период реакции (соответственно 19,6 и 19,0 г/дм³ за 8 ч), что составляет высокий выход 52,9 и 51,3\% от начальной массы субстрата. Кроме того, зависимость концентрации РВ от продолжительности процесса выходит на плато уже через 24 ч гидролиза, а через 72 ч обеспечивается степень конверсии субстратов для Ц1 - 87,5\%, для Ц2 - 86,4 \%. Полученные результаты доказывают одинаковую готовность к ферментации обоих субстратов, несмотря на то, что Ц1 и Ц2 были вовлечены в процесс в различных состояниях: сухом и влажном соответственно. Таким образом, высокая реакционная способность к ферментации данных субстратов обусловлена отсутствием негидролизуемых примесей и особым состоянием целлюлозных волокон. Высокие значения степени полимеризации (1140-1350 ед) и степени кристалличности (67-68\%) не предполагали выход РВ, близкий к 100\%. Отсутствие субстратов через 72 ч в реакционных массах дополнительно подтвердил полный гидролиз обеих целлюлоз, проведенный в одну стадию. Концентрация пентоз в пересчете на ксилозу в конечных гидролизатах Ц1 и Ц2 составила 3,6 и 3,8 г/дм ${ }^{3}$ соответственно, что свидетельствует о полном гидролизе и пентозной части обоих субстратов. 
a)

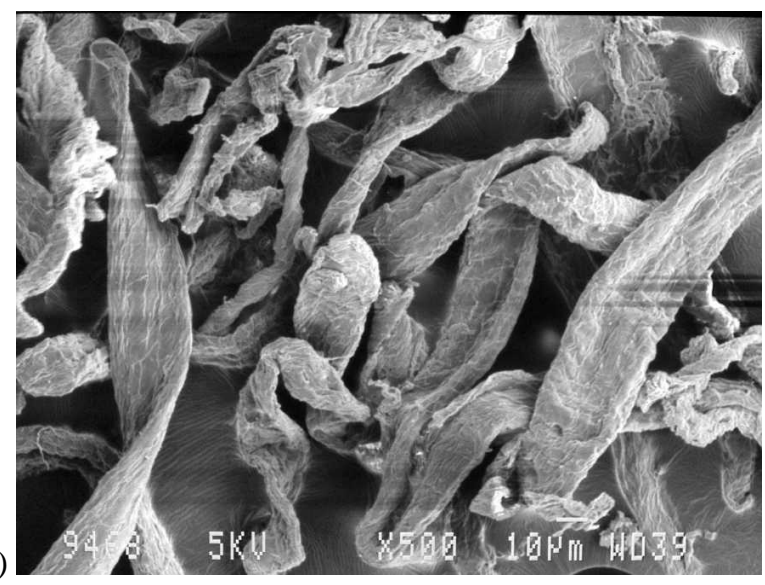

B)
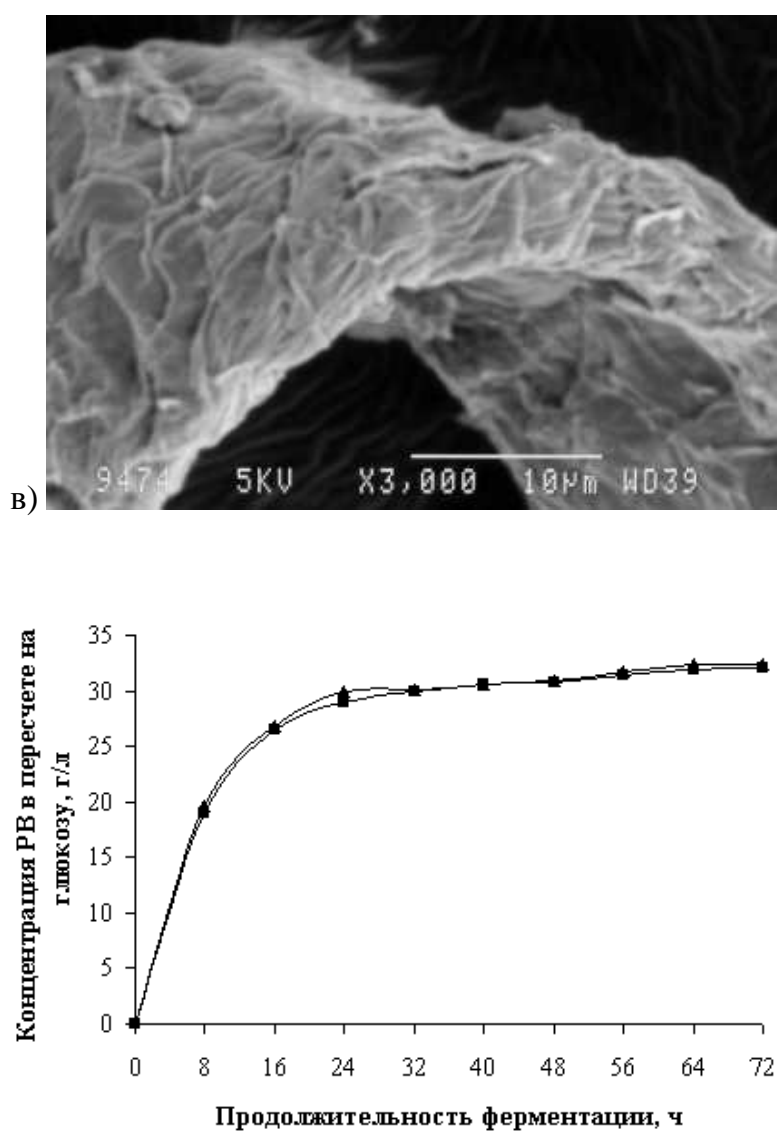

$\leftarrow\llcorner 1 ; \rightarrow-\mathrm{L} 2$

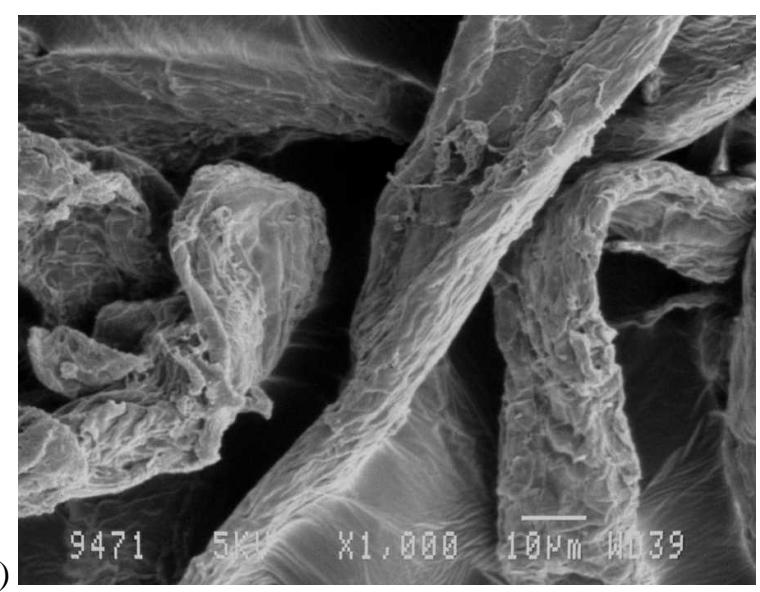

б)

Рис. 1. Фото растровой электронной микроскопии Ц1: а - увеличение $\times 500 ;$ б - увеличение $\times 1000$; в - увеличение $\times 3000$

Рис. 2. Зависимость концентрации РВ в пересчете на глюкозу от продолжительности ферментации образцов Ц1 и Ц2

В литературе отсутствуют примеры исследования ферментативного гидролиза целлюлозы, полученной из плодовых оболочек овса, но данные результаты можно сравнить с материалом статьи [2], в которой описан гидролиз порошковой целлюлозы, полученной из льняного волокна, с характеристиками степени полимеризации 330 ед. и индексом кристалличности (методом РФА) 0,84, начальная концентрация субстрата 25 мг $/ \mathrm{cm}^{3}$. Кривая зависимости концентрации РВ от продолжительности гидролиза льняной целлюлозы имеет сложный характер, конечная концентрация РВ в гидролизате через 48 ч достигает всего лишь 4,5 мг $/ \mathrm{cm}^{3}$, что соответствует степени конверсии $18 \%$. Аналогичными по форме кривых с нашими результатами зависимости прироста РВ от продолжительности гидролиза характеризуются ферментации порошковых целлюлоз, полученных из лиственной целлюлозы, со степенью полимеризации 210-260 ед. и индексами кристалличности $0,00-0,15$. Но конечные концентрации РВ через 48 ч этих аморфных образцов дос-

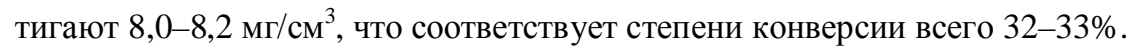


Подчеркивая зависимость выхода ферментации от степени кристалличности целлюлозы, авторы статьи [6] приводят описания ферментативного гидролиза целлюлозы, полученной из мискантуса трехступенчатой делигнификацией хлоритом натрия. В данной статье образцы целлюлозы определенного химического состава (51\% целлюлозы и 38\% гемицеллюлоз) со степенью кристалличности целлюлозы 46-56\% ферментировали с выходами глюкозы 70-90\% (в пересчете на целлюлозу в субстрате). Но предварительно столь успешной ферментации все образцы субстрата были подвержены измельчению на шаровой мельнице в течение 24 ч и разделению измельченного материала на четыре фракции по крупности путем просеивания через ряд сит с диапазоном 63-355 мкм.

Другими словами, высокая реакционная способность к ферментации целлюлозы из плодовых оболочек овса со степенью кристалличности 67-68\% может быть объяснена не только природой субстрата, но и особым химическим способом его получения.

Ферментативный гидролиз Ц2 с различными концентращиями субстрата. Вторым этапом работы было исследование ферментативного гидролиза субстрата Ц2 при его различных начальных концентрациях. Как правило, в исследованиях гидролиза целлюлозы ферментируют субстрат с концентрацией 10 30 г/дм³ [18]. Известно, что повышение концентрации субстрата приводит к снижению скорости ферментации и выхода РВ $[8,19]$. Но получение концентрированных растворов сахаров обосновано стремлением проведения последующих процессов биоконверсии, например в этанол. Для получения бражки с содержа-

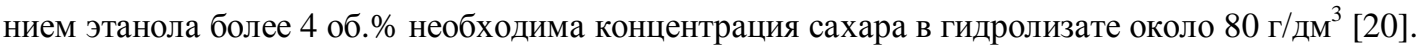

С целью дальнейшего масштабирования ферментации в водной среде были проведены исследования гидролиза влажных образцов Ц2 с концентрациями субстрата: 15; 30; 60; 90; 120 г/дм³. Полученные результаты представлены на рисунке 2 в виде зависимостей концентрации РВ в пересчете на глюкозу от продолжительности ферментации для указанных опытов.

Сравнение кинетических зависимостей, полученных при ферментации целлюлозы с различной исходной концентрацией, показывает, что с увеличением исходной концентрации субстрата конечная концентрация РВ в гидролизате возрастает.

Опыты с концентрацией субстрата 15 и 30 г/дм³ имеют практически одинаковый характер кинетических зависимостей, демонстрируя высокую начальную скорость гидролиза и выход на плато без последующего увеличения концентрации РВ через 16 ч реакции. В опытах с концентрацией субстрата 60; 90 и 120 г/дм³ начальные скорости реакции также высокие, но выход на плато наблюдается лишь через 32-40 ч ферментации.

Используя полученные результаты, можно прогнозировать, что ферментация Ц2 в водной среде с исходной концентрацией в интервале 60-120 г/дм³ позволит получить гидролизаты с концентрациями РВ в диапазоне 54-87 г/дм³, а также произвести выбор концентрации субстрата для получения гидролизата с заданной концентрацией РВ.

Следует подчеркнуть, что повышение концентрации субстрата выше 120 г/дм ${ }^{3}$ ограничено высокой вязкостью реакционной массы, представляющей собой набухшую влажную целлюлозу в ацетатном буфере, которая при интенсивном горизонтальном перемешивании разжижается только через 16 ч процесса.

С целью обобщения полученных результатов приведена зависимость выхода РВ в пересчете на глюкозу от начальной концентрации субстрата на рисунке 4.

Полученная зависимость имеет линейный характер и показывает, что при увеличении концентрации субстрата от 15 до 120 г/дм³ происходит уменьшение выхода РВ от 88 до 65\%. Это явление можно объяснить и частичным ингибированием ферментов продуктами реакции при концентрации субстрата более 30 г/дм ${ }^{3}$ и возможной необратимой сорбцией ферментов на субстрате с выводом катализатора из реакционной среды. Проведение ферментации с отводом продуктов реакции обеспечит получение гидролизата с высоким содержанием РВ. К способам решения данной проблемы можно отнести не только использование специального оборудования с мембранной фильтрацией гидролизата, но и проведение одновременно двух процессов: гидролиза и сбраживания, а также многостадийного (более двух) процесса ферментативного гидролиза с добавлением свежей порции ферментов [7, 20]. 


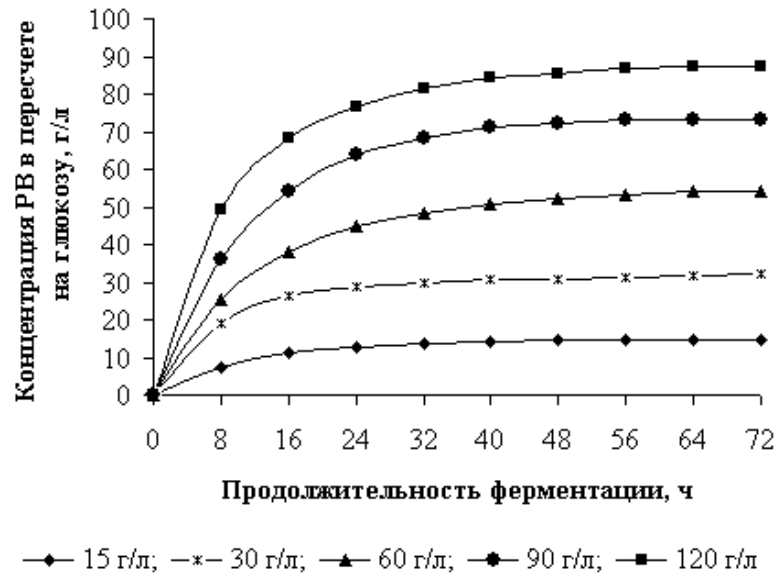

Рис. 3. Зависимость концентрации РВ в пересчете на глюкозу от продолжительности ферментации для опытов с различной исходной концентрацией субстрата Ц2

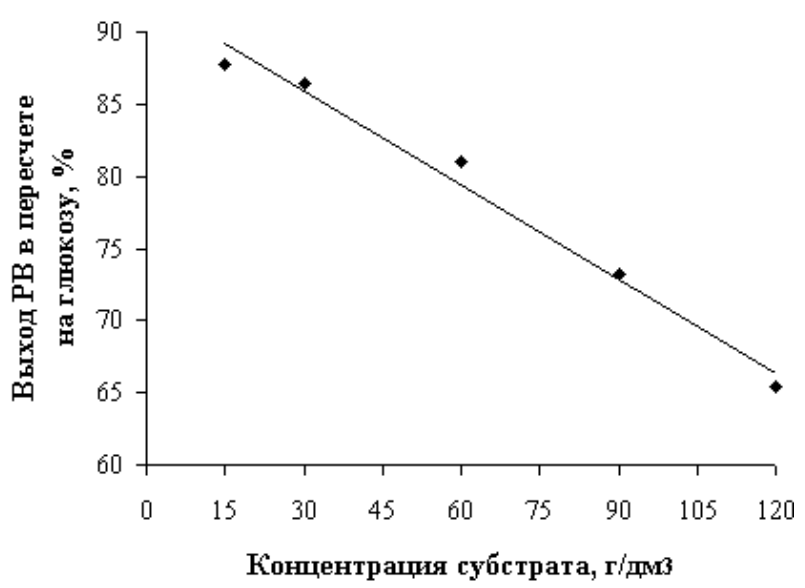

Рис. 4. Зависимость выхода РВ в пересчете на глюкозу через 72 ч гидролиза от исходной концентрации субстрата Ц2

В результате проведенных исследований можно рекомендовать масштабирование по объему одностадийного гидролиза целлюлозы плодовых оболочек овса в стандартном оборудовании с исходной концентрацией не более 60 г/дм³ ${ }^{3}$ Повышение указанной концентрации до 120 г/дм³ нецелесообразно, так как приводит к снижению выхода РВ с 81 до 65\%, т.е. потери негидролизованного субстрата по окончании процесса составят от 19 до 35\%. Выбор концентрации субстрата 60 г/дм³ обоснован тем, что при этом в ферментативном гидролизате достигается концентрация РВ, пригодная для сбраживания, а потери целлюлозы не превышают $20 \%$.

\section{Выводы}

Используя «Брюзайм BGX» и «Целлолюкс-А» исследован гидролиз технических целлюлоз, полученных комбинированным способом из плодовых оболочек овса, и показано, что, образцы обладают высокой реакционной способностью: значительной начальной скоростью гидролиза (51,3-52,9\% за 8 ч) и высоким выходом РВ в пересчете на глюкозу по окончании гидролиза (86,4-87,5\%), несмотря на высокие значения степени полимеризации и степени кристалличности.

Исследован ферментативный гидролиз целлюлоз при различных концентрациях субстрата в пределах 15-120 г/дм³ . Выявлено линейное уменьшение выхода через 72 ч РВ от 88 до $65 \%$ с ростом начальной концентрации субстрата. С целью дальнейшего масштабирования процесса по объему рекомендовано проводить гидролиз при концентрации субстрата не более 60 г/дм³ , так как при этом в гидролизате достигается концентрация РВ, пригодная для сбраживания, и потери субстрата составляют всего 19\%. Дальнейшее повышение исходной концентрации целлюлозы до 120 г/дм³ нецелесообразно и приводит к снижению выхода РВ с 81 до 65\% и, соответственно, увеличению потерь непрореагировавшего субстрата до $35 \%$.

\section{Сиисок литературы}

1. Борисенков М.В., Шубаков А.А., Кочева Л.С., Карманов А.П. Действие ферментов на солому злаков // Химия растительного сырья. 2011. №4. С. 19-23.

2. Торлопов М.А., Тарабукин Д.В., Фролова С.В., Щербакова Т.П., Володин В.В. Ферментативный гидролиз порошковых целлюлоз, полученных различными методами // Химия растительного сырья. 2007. №3. С. 69-76.

3. Lloyd TA and Wyman CE, Combined sugar yields for dilute sulfuric acid pre-treatment of corn stover followed by enzymatic hydrolysis of the remaining solids // Bioresource Technol. 2005. Vol. 96. Pp. 1967-1977.

4. Синицын А.П., Гусаков А.В., Черноглазов В.М. Биоконверсия лигноцеллюлозных материалов. М., 1995. 224 с.

5. Silverstein R.A., Chen Y., Sharma-Shivappa R.R., Boyette M.D., Osborne J. A comparison of chemical pretreatment methods for improving saccharification of cotton stalks // Bioresource Technology. 2007. Vol. 98. Pp. 3000-3011.

6. Yoshida M., Liu Y., Uchida S., Kawarada K., Ukagami Y., Ichinose H., Kaneko S., Fukuda K. Effects of cellulose crystallinity, hemicellulose, and lignin on the enzymatic hydrolysis of Miscanthus sinensis to monosaccharides // Bioscience, Biotechnology and Biochemistry. 2008. Vol. 72. Pp. 805-810. 
7. Yu Z., Jameel H., Chang H.-M., Philips R., Park S. Evaluation of the Factors Affecting Avicel Reactivity Using Multi-Stage Enzymatic Hydrolysis // Biotechnology and Bioengineering. 2012. Vol. 5. Pp. 1449-1463.

8. Taherzaden M.J., Karimi K. Enzyme-based hydrolysis processes for ethanol from lignocellulosic materials: a review // BioResources. 2007. Vol. 2, N4. Pp. 707-738.

9. Оболенская А.В., Ельницкая 3.П., Леонович А.А. Лабораторные работы по химии древесины и целлюлозы. M., $1991.320 \mathrm{c}$.

10. ГОСТ 25438-82. Целлюлоза для химической переработки. Методы определения характеристической вязкости. M., $1982.20 \mathrm{c}$.

11. Алешина Л.А., Люханова И.В., Будаева В.В., Золотухин В.Н., Митрофанов Р.Ю., Сакович Г.В. Результаты рентгеноструктурного анализа недревесных целлюлоз // Ученые записки Петрозаводского государственного университета. 2011. №8. С. 114-117.

12. Герасименко В.Л. Лабораторные методы определения глюкозы: метод. рекомендации. Ижевск, 2002. 6 с.

13. Вешняков В.А., Хабаров Ю.Г., Камакина Н.Д. Сравнение методов определения редуцирующих веществ: метод Бертрана, эбулиостатический и фотометрический методы // Химия растительного сырья. 2008. №4. С. 47-50.

14. Макарова Е.И., Будаева В.В. Определение глюкозы на спектрофотометре UNICO UV-2804 // Технология и оборудование химической, биотехнологической и пищевой промышленности: мат. 3-й Всерос. науч.-практ. конф. студентов, аспирантов и молодых ученых с междунар. участием. Бийск, 2010. Ч. 1. С. 215-218.

15. Золотухин В.Н., Будаева В.В. Сравнительная характеристика целлюлоз, полученных щелочной делигнификацией из нетрадиционного сырья // Новые достижения в химии и химической технологии растительного сырья: мат. V Всерос. конф. Барнаул, 2012. С. 75-77.

16. Непенин Н.Н. Технология целлюлозы. Т. 1: Производство сульфитной целлюлозы. М., 1976. 748 с.

17. Макарова Е.И., Будаева В.В., Митрофанов Р.Ю. Использование мультиэнзимных композиций для гидролиза нетрадиционного целлюлозосодержащего сырья // Ползуновский вестник. 2010. №4. С. 192-198.

18. Новый справочник химика и технолога. Сырье и продукты промышленности органических и неорганических веществ. СПб., 2006. Ч. ІІ. С. 924.

19. Патент №014759 (ЕА). Ферментативный гидролиз биомасс, имеющих высокое содержание сухого вещества / Фелбю К., Ларсен Я., Йергенсен Х., Вибе-Педерсен Я. 30.06.2008.

20. Макарова Е.И. Результаты ферментации целлюлозы мискантуса в ацетатном буфере и водной среде // Химия в интересах устойчивого развития. 2013. Т. 21, №2. С. 219-225.

Поступило в редакичию 13 сентября 2012 г.

После переработки 4 декабря 2012 2. 
Makarova E.I. , Budaeva V.V., Skiba Ye.A. ENZYMATIC HYDROLYSIS OF CELLULOSE FROM OAT HUSKS AT VARIOUS SUBSTRATE CONCENTRATIONS

Institute for Problems of Chemical and Energetic Technologies, Siberian Branch of the Russian Academy of Sciences, Socialisticheskaya str., 1, Biysk, 659322 (Russia),e-mail: ipcet@mail.ru

Pulps derived from oat husks by the combined method (prehydrolysis, alkaline delignification, treatment with nitric acid solution) are shown to posses high reactivity towards fermentation upon hydrolysis with the mixed enzyme preparations BrewZyme BGX and CelloLux-A. The dependence of the increment in reducers on the original concentration of the substrate in the range of 15 to $120 \mathrm{~g} / \mathrm{L}$ is studied, and the linear decrease in the final yield of reducers (in $72 \mathrm{~h}$ ) ranging from 98 to $73 \%$ with increasing original substrate concentration is revealed. concentration

Keywords: pulp, oat husk, combined method, enzymatic hydrolysis, reducers, BrewZyme BGX, CelloLux-A, substrate

\section{References}

1. Borisenkov M.V., Shubakov A.A., Kocheva L.S., Karmanov A.P. Khimiia rastitel'nogo syr'ia, 2011, no. 4, pp. 19-23. (in Russ.).

2. Torlopov M.A., Tarabukin D.V., Frolova S.V., Shcherbakova T.P., Volodin V.V. Khimiia rastitel'nogo syr'ia, 2007, no. 3, pp. 69-76. (in Russ.).

3. Lloyd T.A., Wyman C.E. Bioresource Technology, 2005, vol. 96, pp. 1967-1977.

4. Sinitsyn A.P., Gusakov A.V., Chernoglazov V.M. Biokonversiia lignotselliuloznykh materialov. [Bioconversion of lignocellulosic materials]. Moscow, 1995, 224 p. (in Russ.).

5. Silverstein R.A., Chen Y., Sharma-Shivappa R.R., Boyette M.D., Osborne J. Bioresource Technology, 2007, vol. 98, pp. 3000-3011.

6. Yoshida M., Liu Y., Uchida S., Kawarada K., Ukagami Y., Ichinose H., Kaneko S., Fukuda K. Bioscience, Biotechnology and Biochemistry, 2008, vol. 72, pp. 805-810.

7. Yu Z., Jameel H., Chang H.-M., Philips R., Park S. Biotechnology and Bioengineering, 2012, vol. 5, pp. 1449-1463.

8. Taherzaden M.J., Karimi K. BioResources, 2007, vol. 2, no. 4, pp. 707-738.

9. Obolenskaia A.V., El'nitskaia Z.P., Leonovich A.A. Laboratornye raboty po khimii drevesiny $i$ tselliulozy. [Laboratory work on the chemistry of wood and cellulose]. Moscow, 1991, 320 p. (in Russ.).

10. GOST 25438-82. Tselliuloza dlia khimicheskoi pererabotki. Metody opredeleniia kharakteristicheskoi viazkosti. [State Standard 25438-82. Dissolving wood pulp. Methods for determining the intrinsic viscosity.]. Moscow, 1982, 20 p. (in Russ.).

11. Aleshina L.A., Liukhanova I.V., Budaeva V.V., Zolotukhin V.N., Mitrofanov R.Iu., Sakovich G.V. Uchenye zapiski Petrozavodskogo gosudarstvennogo universiteta, 2011, no. 8, pp. 114-117. (in Russ.).

12. Gerasimenko V.L. Laboratornye metody opredeleniia gliukozy: Metodicheskie rekomendatsii. [Laboratory methods for the determination of glucose: Guidelines]. Izhevsk, 2002, 6 p. (in Russ.).

13. Veshniakov V.A., Khabarov Iu.G., Kamakina N.D. Khimiia rastitel'nogo syr'ia, 2008, no. 4, pp. 47-50. (in Russ.).

14. Makarova E.I., Budaeva V.V. Tekhnologiia i oborudovanie khimicheskoi, biotekhnologicheskoi i pishchevoi promyshlennosti: materialy 3-i Vserossiiskoi nauchno-prakticheskoi konferentsii studentov, aspirantov $i$ molodykh uchenykh s mezhdunarodnym uchastiem. [Technology and equipment for the chemical, biotechnology and food industries: Proceedings 3rd All-Russian scientific-practical conference of students and young scientists with international participation]. Bijsk, 2010, part 1, pp. 215-218. (in Russ.).

15. Zolotukhin V.N., Budaeva V.V. Novye dostizheniia v khimii i khimicheskoi tekhnologii rastitel'nogo syr'ia: materialy $\mathrm{V}$ vserossiiskoi konferentsii [Technology and equipment for the chemical, biotechnology and food industries: Proceedings 3rd All-Russian scientific-practical conference of students and young scientists with international participation]. Barnaul, 2012, pp. 75-77. (in Russ.).

16. Nepenin N.N. Tekhnologiia tselliulozy. Tom 1. Proizvodstvo sul'fitnoi tselliulozy. [Technology cellulose. Volume 1. Manufacture of sulphite pulp.]. Moscow, 1976, 748 p. (in Russ.).

17. Makarova E.I., Budaeva V.V., Mitrofanov R.Iu. Polzunovskii vestnik, 2010, no. 4, pp. 192-198. (in Russ.).

18. Novyi spravochnik khimika i tekhnologa. Syr'e i produkty promyshlennosti organicheskikh $i$ neorganicheskikh veshchestv. Ch. II. [The new directory chemist and technologist. Raw materials and industrial organic and inorganic substances. Part II.]. St. Petersburg, 2006, 924 p. (in Russ.).

19. Patent 014759 (EA). 30.06.2008. (in Russ.).

20. Makarova E.I. Khimiia v interesakh ustoichivogo razvitiia, 2013, vol. 21, no. 2, pp. 219-225. (in Russ.). 